\title{
Reading Experience as Communitist Practice: Indigenous Literatures and Community Service-Learning
}

\author{
JD McDougall, Nancy Van Styvendale
}

\begin{abstract}
Our paper analyzes a community service-learning class on Indigenous literatures from the perspectives of graduate student and instructor. Enacting Jace Weaver's theory of communitism (a portmanteau of "community" and "activism"), the class asks students to read Indigenous texts through the lens of their experiences at communitybased organizations in Saskatoon, Saskatchewan, and to consider how these readings shape their interactions with and responsibilities to Indigenous communities. First, the instructor discusses the complexities of community service-learning as an engaged approach to literary study in a settler colonial context. Informed by Tomson Highway's novel Kiss of the Fur Queen, the second author then analyzes their ${ }^{1}$ contributions to the social justice club at Oskāyak High School, highlighting Oskāyak's unique academic culture, where music and Indigenous language learning are incorporated into the fabric of everyday life. Ultimately, we argue that a communitist approach to Indigenous literary scholarship creates or furthers relationships with/in and responsibility to Indigenous communities, while encouraging an integrative approach to literary study through critical embodiment.
\end{abstract}

KEYWords Indigenous literatures, community service-learning, Indigenous education, Cree philosophy

In That the People Might Live: Native American Literatures and Native American Community (1997), Cherokee scholar Jace Weaver proposes the term "communitism" — a portmanteau of "community" and "activism"- to describe a central tenet of Indigenous literatures. "Literature is communitist," he explains, "to the extent that it has a proactive commitment to Native community" (p. 43). Community is of the "highest value to Indigenous peoples, and fidelity to it is a primary responsibility" (p. 37). Whereas white settler communities are often "defined primary [sic] by residence or by agreement with sets of intellectual beliefs" (p. 37), Indigenous communities are more commonly defined by kinship relations and responsibilities. Informed by Weaver's concept, this paper reflects on a graduate class entitled "Connecting Aboriginal ${ }^{2}$ Literatures and Community Service-Learning," which co-author and professor

\footnotetext{
${ }^{1} \mathrm{JD}$ uses they/them pronouns. As this usage may cause confusion in a co-authored paper of this nature, we avoid pronouns where possible.

2 "Aboriginal" was used in the 2013 course title, reflecting popular terminology of the time. When nation-specific terms can be used, they are preferred; and for a definition that gestures towards international solidarities, "Indigenous" is now commonly used.
} 
Nancy Van Styvendale developed and taught in 2013 in the Department of English at the University of Saskatchewan. Co-author and PhD student JD McDougall was a member of the class, along with five other graduate students who worked with Indigenous community-based organizations as a way of enacting communitist values, and read these experiences alongside textual representations of community, activism, and artistic expression in Indigenous literatures. By situating the study of Indigenous literatures in Indigenous communities, the class aimed to theorize a relational, embodied, and communitist approach to Indigenous literatures that would enact Weaver's (1997) notion of a "proactive commitment" to Indigenous communities (p. 43).

Weaver (1997) suggests that "ultimately, no Native scholarship can be produced in isolation. It must be a communal effort" (p. xiv). Our paper takes this assertion to heart. We have structured our reflection in two main parts, each of which emphasizes our individual perspectives as instructor and student, respectively. In the first section, Nancy discusses the development and theoretical premise of the class. As a case study of sorts, JD then speaks to their experience in the class and presents a reading of Cree language and music in Tomson Highway's Kiss of the Fur Queen (1998). JD discusses the development of this reading in light of their experience of Cree music, language, and pedagogy at Oskāyak High School, an Indigenous high school in Saskatoon, Saskatchewan, Canada where they did their service-learning placement. Ultimately, we suggest that a communitist approach to Indigenous literary scholarship creates or furthers relationships with/in and responsibility to Indigenous communities, while encouraging an integrative approach to learning and thinking about literature through critical embodiment and lived experience.

\section{Community Service-Learning as Communitist Intervention: Nancy's Reflections on Course Development and Implementation}

Throughout this paper, we "put[...] ourselves forward," following Absolon and Willett's (2005) article of the same name, which we studied in class and which discusses the ethical imperative of location-both personal and place-based-to Indigenous research methodologies. To begin, then, I (Nancy) am a white settler scholar of Indigenous North American literatures, trained in the discipline of English. My graduate studies took place during the first decade of the 21 rst century and were not informed by community-based pedagogies or methodologies; like many literary scholars of my generation, I spent most of my time in the classroom or my office, studying texts. I was steeped in literary depictions of Indigenous communities (and the importance of relational responsibilities), but the conventions of the discipline did not invite engagement with or responsibility to Indigenous communities. In resistance to this training and as a way of enacting the obligations I now understand myself to have, as a settler, to building and sustaining ethical relations with Indigenous peoples, specifically in Treaty 6 territory and the Métis homeland where I live, I have since collaborated with Indigenous community partners on a range of community-based initiatives. The CSL class we analyze below was one of my first formative attempts to move my approach to literary study beyond the confines of the academy and the conventions of the discipline. 
The separation of literary study from community contexts and political struggles has roots in the development of English as a discipline in the $19^{\text {th }}$ century. Terry Eagleton (2008) discusses how the rise of English Studies at this time was intimately connected to the idea of art as an "isolatable experience," "alienat[ed] from social life" (p. 18) —an assumption that extends into New Criticism and beyond. ${ }^{3}$ While there are countless examples of art with political import, the approach to art as an end in itself and an escape from the realities of daily life has had an enduring effect on the discipline. This approach is antithetical to Indigenous epistemologies of art as an integrated component of life, in which stories and other creative practices function as history, law, politics, science, and culture. JD's analysis of integrative Cree philosophies, particularly in relation to language and music at Oskāyak High School below, illustrates this point. In contrast to the idea of "art for art's sake" (Justice, 2018, p. 20), Cherokee literary critic Daniel Heath Justice (2018) affirms his preference for CherokeeAppalachian poet Marilou Awiakta's notion of “"art for life's sake'-whereby... art is explicitly, generously engaged with a larger network of relations, influences, and experiences, always with some measure of commitment to articulating Indigenous presence in the world" (p. 21). As in Weaver's analysis, art in this formulation is relational, experiential, and responsible to Indigenous peoples. In response to concerns about the social function of literary study, postsecondary community service-learning literature (mainly composition) classes began to appear in the mid to late 1990s and continue today (Grobman \& Rosenberg, 2015, p. 6), albeit as a relatively minor approach.

In the field of Indigenous literatures, the separation between literary/theoretical content and the ways in which this content is taught and researched can be particularly striking because of the politics of the literature itself. If Indigenous literatures are communitist, then what of Indigenous literary study? That the field has turned increasingly to such questions is evidenced by the theme of the inaugural 2015 ILSA (Indigenous Literary Studies Association) conference"The Arts of Community" —as well as by ILSA's commitment to hold alternating conferences in Indigenous communities/reserves, with local hosts, knowledge keepers, and protocols. ${ }^{4}$ In their afterword to the special issue of Canadian Literature on Indigenous Literatures and the Arts of Community (2016), a follow-up to the ILSA conference, editors McKegney and Henzi ask "whether 'community' means the same thing(s) in creative and critical contexts; if it doesn't, we wonder if maybe it should and whether this might be the direction in which the Indigenous literary arts are, in fact, guiding us" (para. 1). In response to their question, I would suggest that the conventional ways in which literary scholars are trained can seriously limit our engagement with and accountability to Indigenous communities. Noting that it is "nearly unheard of in literary studies" for scholars to be asked to "identify the purpose of their work," Cree-Métis critic Deanna Reder cites Cree education scholar Margaret Kovach, who calls for research to be "collectively relevant... Purposeful research [is] inseparable from the value in

\footnotetext{
${ }^{3}$ New Criticism is a mid-20th century approach to literary criticism that looks to the text for meaning, rather than the context of the text's production or reception. Close reading, its primary method, looks for meaning in language patterns, and has had a profound impact on literary study.

${ }^{4}$ On alternating years, the ILSA conference is held at the Congress of Social Sciences and Humanities annual meeting.
} 
giving back, that what we do has to assist" (as cited in Reder, 2016, p. 15). This call to purpose and reciprocity, Reder surmises, "is a huge challenge to our field that is only now resonating in our own discussions" (p. 15).

For non-Indigenous students, the limitations of the discipline can mean that we come to engage meaningfully with Indigenous peoples and communitist politics first (or perhaps only) through texts and in the classroom. This was my experience until well into my $\mathrm{PhD}$ program. For some Indigenous students (many of whom are actively engaged in communities outside the university), these limitations may produce or reify a divide between university and community commitments. Although it is crucial, building on the work of Kim TallBear (2017), to problematize any easy community/university binary which locates Indigenous communities as always-already outside the university, ${ }^{5}$ it remains important to consider how the modes of learning embraced in the academy are often at odds with the extra-university community responsibilities of students. I started thinking about the effects of this disjunction during the rise of Idle No More (2012-2013), when a number of Indigenous students in my classes were involved in community organizing, a commitment that in some cases ended up negatively impacting their grades and health. I began to think about how university classes could support and recognize these kinds of commitments as fundamental to academic learning, rather than something to squeeze in —or, worse, something actively at odds with the institution. How could I create opportunities for myself and my students, both Indigenous and non-Indigenous, to build new or strengthen existing relationships, learn from and with communities, and contribute to these communities through activist or other types of community-driven work? What kinds of structural changes could be implemented within my teaching that could facilitate these interactions? If, as Justice (2018) argues, "relationship is the driving impetus behind the vast majority of texts by Indigenous writers," and if "these literary works offer us insight and sometimes helpful pathways for maintaining, rebuilding, or even simply establishing these meaningful connections" (p. xix), then how might scholars of Indigenous literatures (continue to) apply these insights to our teaching and research — in terms of both content and methodso that they too become pathways for relationship and responsibility to community? In my experience, community service-learning has been one method to establish, rebuild, or maintain the meaningful connections of which Justice speaks.

In 2013, with support from a SSHRC Insight Development Grant, I designed a graduate class entitled "Connecting Aboriginal Literatures and Community Service-Learning," which I offered again in 2015 under the title of "Writing Communities: The Praxis of Indigenous North American Literatures." CSL is a mode of experiential learning in which students are partnered with community-based organizations as a component of a course or co-curricular program. CSL courses can be structured in a number of ways, but generally students spend time on-site (usually 20 hours a term), learning about and contributing to the daily operations of the organization, as well as working on a community-driven project (i.e., one defined by the

\footnotetext{
${ }^{5}$ TallBear (2017) usefully complicates the binary of community/university as it is mobilized in the context of communitybased research, which typically assumes that Indigenous communities are external to the university, and that university researchers are from outside Indigenous communities.
}

Engaged Scholar Journal: Community-Engaged Research, Teaching and Learning 
community partner, while also drawing on student strengths). Ideally, both partner and student benefit equally from their relationship. Crucially, CSL asks students to "use their experiences in the community to reflect critically on academic concepts and theories, and vice versa, using classroom content to process and analyze their learning in the community" (Van Styvendale, Buhler, \& McDonald, 2018). This approach dovetails nicely with the kind of critical analysis expected in literary studies, although with CSL, it is one's experience that is to be explored, like a text, and read alongside literary and theoretical texts.

From an antifoundationalist perspective, CSL disrupts normative thinking and prompts reconsideration of entrenched power structures (Butin, 2010), including the preconceived notion of the university as provider of knowledge and expertise, and the community as beneficiary (Himley, 2004). CSL challenges those of us from a range of privileged positions within the university to prioritize community knowledge and interests, and to work collaboratively in service of community-defined processes and ends. It was important to me, particularly as a settler professor, to ask students to think about what it means to engage ethically in the study of Indigenous literatures, to unsettle dominant modes of literary analysis, and to ground our work in a relational context with Indigenous peoples. For students originally from Saskatoon, this grounding provided an opportunity to fulfill their various (Indigenous or settler) responsibilities to Indigenous communities (or to begin to understand what these responsibilities might be), while for students from other provinces or outside the country, it helped situate their studies in the specifics of the territory in which they had arrived. I wanted students, both Indigenous and non-Indigenous, to have the opportunity to learn not only from Indigenous texts but from and with Indigenous peoples. Disrupting my authority as professor, I wanted students to experience their community partners as co-teachers, which is one way that partners often understand their role in CSL (Hitchings, Johnson, \& Tu'Inukuafe, 2018)_albeit an unpaid and often underrecognized role.

In the first iteration of the class, there were six students placed at six different organizations: Oskāyak High School, STR8 UP (an organization for people exiting street gangs), Saskatoon Food Bank and Learning Centre (Adult Education program), Saskatoon Indian and Métis Friendship Centre, People's Free University (a grassroots initiative to provide free postsecondary education), and Saskatchewan Native Theatre Company (now the Gordon Tootoosis Nìkāniwwin Theatre). In the second iteration, a similar array of organizations was involved, with the addition of Idle No More (a grassroots Indigenous movement) and Inspired Minds (a creative writing program for people who are incarcerated). ${ }^{6}$ Co-author JD was placed at Oskāyak High School, where they worked with the school's social worker, Stan Tu'Inukuafe, ${ }^{7}$ to support the Social Justice Club (SJC), a group of youth who met weekly to discuss current issues in the community and participate in activities around anti-racism and poverty reduction.

\footnotetext{
${ }^{6}$ I added these groups, Idle No More in particular, because I wanted to encourage discussions about how communitism is different in different contexts - a non-profit organization is quite different from a school, and different still from a grassroots movement (which is not reliant on state funding and restrictions).

${ }^{7}$ We thank Stan Tu'Inukuafe for his commitment to working with CSL students and for reading a draft of this article and providing comments. He has given permission for his name to be used.
} 
JD joined in these events, took photos and wrote posts for the school's blog, and created a multimedia presentation about these activities for the Assembly of First Nations' Youth Summit.

In both iterations of the course, students attended a three-hour weekly seminar and spent two hours a week at their community-based organizations, working on (sometimes seemingly mundane) tasks related to daily operations. Although not all CSL courses include such a requirement, my intention was to have students spend time at their host organization without a necessarily pre-determined or instrumentalized end. This requirement was informed by the importance of building relationships and establishing trust with community in engaged scholarship more generally, as well as the core animating commitment to relationality and relational accountability in Indigenous communities specifically. Being asked to complete routine tasks - such as serving lunch (as JD describes below) or even cleaning floors or toilets (as I and students in my other CSL classes have done) - frees up time for staff members to do other, more substantive work; underscores the importance of showing up and pitching in as crucial to community relations; and complicates the usual university/community hierarchy in which faculty and students help underserved communities with their academic and professional skills.

In addition to spending time at the organization-what Métis scholar Janice Cindy Gaudet (2019) calls a "visiting methodology" in another context—students were responsible for completing a project designed in collaboration with their $\mathrm{CBO}$ supervisor. In an interview about engaged learning from a community partner perspective, Oskāyak High School social worker Stan Tu'Inukuafe explains the "unequal level of power" between university and community that is sometimes amplified in service-learning (Hitchings, Johnson, \& Tu'Inukuafe, 2018, p. 276): "[I have often been] approached by the university or university students who need something, like to fulfill a requirement for example.... It often feels like the university will work with us as long as it is on their terms.... It's not really an equal, level playing field" (p. 276). Because of the university's colonial history of extracting knowledge and resources from Indigenous communities (Gaudry 2018; Smith, 1999), while simultaneously positioning itself as the source of superior knowledge, it was especially important that both the students and I approached their CSL partners with humility, respect, and a desire to collaborate on whatever literary or arts-based project the partner deemed most appropriate (within the scope of their skills).

Because the class took place in the city of Saskatoon and the students were placed at urban organizations, I selected literary and theoretical texts with a focus on urban Indigenous topics that would correspond with issues relevant to the students' placements. ${ }^{8}$ Many of the students were partnered with educational organizations or initiatives, and so I chose a number

\footnotetext{
${ }^{8}$ As a practical consideration, I would note that setting in motion a conversation between literary text, theory, and experiential knowledge is a lot to do in one three hour class, and sometimes, possibly because students had the texts in common but not their community experiences, the latter were left out of the discussion. One solution embraced by other CSL practitioners is group placements and projects, where students collaborate not only with their community partner but with each other; of course, community partner capacity must be considered in this instance, as not all partners are able to take on multiple students (see Hitchings, Johnson, and Tu'Inukuafe, 2018, for more on CSL partner capacity).
} 
of texts that explore both settler colonial and Indigenous forms of education, one of which was Tomson Highway's Kiss of the Fur Queen (1998), which depicts the residential school experience of two Cree youth, their subsequent alienation at a primarily white high school in Winnipeg, and as JD will discuss, their survivance through Cree language, story, and music. My goal in selecting these texts was not to have students make straightforward comparisons between textual representations and lived experience (one of the potential dangers of literary CSL), but for us collectively to theorize how literary texts construct experience, and how these constructions might influence and deepen not only our understanding of our experiences in the community, but our actions and interactions there as well.

To prepare students for their work, I also incorporated literary and theoretical texts that address relationship-building and ethical collaboration with/in Indigenous communities. ${ }^{9}$ While there is little scholarship that explores CSL as a mode of engagement with Indigenous communities (Taylor et al., 2015), specificaly in the settler colonial context of Canada, Margaret Himley (2004) provides a critical caution about the limitations of service-learning. Drawing attention to the roots of service in the volunteerism of white middle- and upper-class women in low-income racialized communities, Himley interrogates how CSL can unwittingly duplicate the civilizing mission of the colonial project, particularly when the service students provide is framed as charity. As she observes, "[R]egardless of a student's actual economic status or social identity, the dominant version of the rhetoric of community service may position each and every community service student in a privileged way-as the one who provides the service, as the one who donates time and expertise, as the one who serves down, as the one who writes up" (p. 430). Some of the popular discourses in the field of literary CSL-i.e., literature as a means of teaching (mainly white, middle class students) compassion, empathy, and an appreciation of our "difference and shared humanity" (Grobman \& Rosenberg, 2015, p. 17) — strike me as deeply implicated in settler pathologizing and anthropological othering, masquerading as liberal benevolence, which Himley critiques.

There is, of course, a long history of critical (Mitchell, 2008) or justice-oriented CSL (Westheimer \& Kahne, 2004) that attempts to problematize what Lori Pompa (2013) calls "charity or the 'helping' modality" (p. 24) and to move away from service-learning toward colearning. Many critics trouble the very idea of service-learning for how "it invokes the categories of 'server' and 'served," and thus "can be seen to terminologically enshrine unequal power relations between providers and recipients of 'service' activities” (Aujila \& Hamm, 2018, p. 21). In the first iteration of the class, we discussed the inherent problematics of CSL, making ourselves aware of how it continues to be shaped by the university as a colonial institution and settler colonial structures and relations more broadly. Simultaneously, we considered how CSL, as Dan Butin (2003) explains, should be centered on the four core principles of respect, reciprocity, relevance, and reflection, which resonate with five key principles commonly associated with Indigenous research methodologies: respect, reciprocity, relevance, relational

\footnotetext{
${ }^{9}$ In subsequent engaged learning classes, I more explicitly encouraged insight into the dynamics of collaboration within and between Indigenous communities, as well as between settler and Indigenous partners. To this end, I assigned articles by Gaudry (2011), TallBear (2017), Innes (2009), and Henry, Tait, and STR8 UP (2016).
} 
accountability, and responsibility (Johnston, McGregor, \& Restoule, 2018). Mali Bain (2018) observes that CSL's foundation in principles of respect and reciprocity corresponds with Indigenous worldviews that centre good relations, ${ }^{10}$ while Michael McNally (2004) outlines the intersections of Anishinaabe pedagogy and CSL, focusing on four features of the former: the privileging of oral, relational, and situational knowledge transmission (p. 605); the responsibility of teachers and learners to use their knowledge for community well-being (p. 606); the importance of active, experiential learning (p. 607); and the assumption of knowledge and reflection as holistic - that is, as interrelated with its larger context-in contrast to the standard disciplinary approach, which often segments learning (p. 608). ${ }^{11}$

Given these connections, and recognizing the colonial paternalism that haunts CSL to varying degrees, the second iteration of the class was oriented away from CSL as a specific model of engagement and towards engaged learning and co-learning models. This decision does not elide current settler colonial conditions and their impact on postsecondary learning, but frames engaged learning more specifically in Indigenous epistemologies of kinship and relational accountability. JD's discussion below, which highlights the centrality of Cree ways of knowing to everyday life at Oskāyak High School, is part of what motivates me to continue to learn about and draw more deeply from Indigenous values, pedagogies, and methodologies (particularly those of prairie Indigenous peoples) in my engaged learning classes. Importantly, this does not necessarily mean that the concept of service should be discarded, but instead, that it should be understood on Indigenous terms. In her critique of service and reciprocity as they are commonly conceptualized in CSL, Swapna Padmanabha (2018) explains that "within Indigenous pedagogy, transferring knowledge is often dependent upon service, and service is understood as a form of reciprocity" (p. 150). To illustrate, she tells a story about a woman who peels potatoes for her grandmother, visiting and fulfilling her relational obligations, while learning from the stories her grandmother tells. Padmanabha's anecdote reveals that service is important, but it is obviously not the service of the "elevated do-gooder," but rather, an integrated component of "learning as being in relationship" (p. 153). It is this type of servicelearning that animates JD's discussion below.

As JD describes, relationships were crucial to the learning they experienced at Oskāyak High School. These relationships, forged through their service to the Social Justice Club (SJC), provided the experiential groundwork from which they interpreted Indigenous literary and theoretical texts, which in turn shaped their CSL experience. JD considers the significance of their service to the SJC as an embodiment of relational accountability and reciprocity akin to what Padmanabha details above. They analyze Tomson Highway's novel Kiss of the Fur Queen alongside the lived experience of CSL at Oskāyak, using Highway's "Why Cree is the Sexiest

\footnotetext{
${ }^{10}$ See Padmanabha (2018) and TallBear (2017) for important critiques of the ways in which "reciprocity" is mobilized in the context of CSL and community-based research, respectively. TallBear proposes that "standing with" rather than "giving back" is a more appropriate framework for Indigenous scholars doing work in their own or with other Indigenous communities.

${ }^{11}$ While specific to an Anishinaabe context, these approaches can be applied (with caution) to some other Indigenous contexts. What I have learned about Cree pedagogy from living on the prairies, for example, resonates with these principles. See Goulet \& Goulet (2014) for more on Cree pedagogies.
}

Engaged Scholar Journal: Community-Engaged Research, Teaching and Learning 
of All Languages" as a theoretical framework for considering Cree ways of being, learning, and thinking with regard to language. This framework is extended to Highway's treatment of music and learning in Kiss of the Fur Queen, and to JD's encounters with music and the educational environment at Oskāyak.

\section{JD's Service and Reading: Grounding Text and Experience}

I wish to locate myself, as Nancy outlined earlier, in accordance with Absolon and Willett's (2005) approach of ethically acknowledging my relation to this work. I am a Métis graduate student who, at the time of this course, was in the early stages of my PhD coursework. I had limited academic experience with Indigenous texts, though as a result of this class and Nancy's encouragement, came to understand that my own position in academia need not rest on a distancing or negation of my interest in them. Centering Indigenous literatures in my scholarship became ethically necessary to me as an acculturated Métis person who had always been taught to meet mainstream Euro-Canadian society where it lived and to transcend, as it were, my background, to prove it irrelevant rather than coming into it on a more radical level. To simplify a complex story, my prior engagements with the issues discussed in the course were primarily non-academic, decolonial thought being more a feature of my politics rather than its central obligation and animation at that time. My background with community involvement was similarly limited, and like Nancy, my academic experience throughout secondary and postsecondary schooling was not community-based.

As part of my work for this course, I was placed at Oskāyak High School, described by Buhler, Settee, and Van Styvendale (2015) as "Saskatoon's only public Indigenous High School," which "follows the principles of the Indigenous survival school movement initiated close to forty years ago in Canada to work with Indigenous educational concerns and make educational institutes more accessible to marginalized Indigenous communities" (p. 98-99). ${ }^{12}$ As a part of its mandate, Oskāyak provides multiple institutional supports to its students in order to "ensure that they have the best opportunity to pursue educational goals and achieve academic success" (Lessard, 2015, p. 24). Their holistic model of care advances "Indigenous ways of supporting students" as "a strength-based approach to providing services" (Lessard, 2015, p. 26). My role was to assist the school's Social Justice Club (SJC), which was teacherled and well-attended at lunch hour. From the outset of the course, Nancy made it clear that our objectives were to carry out whatever tasks and projects the community partners felt were most important. The SJC needed someone to bring meals from the kitchen to the library at the beginning of lunch hour, so that the club could make the most of their short allotted time without having to wait in the lunch line. Through this task, I was able to help fulfill Oskayak's student-centered mandate, which includes providing "nutrition, breakfast, and lunch" in support of holistic education (which considers the physical, mental, emotional, and spiritual dimensions of human experience), as well as participate in the sharing of food, "a central aspect of Indigenous cultural practice" and community building (Buhler, Settee,

\footnotetext{
12 See also: Haig-Brown, C., Hodgson-Smith, C. L., Regnier, R., \& Archibald, J. (1997).
} 
\& Van Styvendale, 2014, p. 197). During meetings, I would take minutes and help the group cover their agenda, before cleaning up afterward. They also requested my help with a blog attached to the school's main site, featuring photos and videos that I would take at events and assemble into posts complete with short write-ups-mobilizing my humanities background with a view toward communicating Oskāyak's vision and student life to the wider community. My contributions, while primarily procedural, helped to further Oskāyak's institutional goals as well as to establish relationships with students and staff — in some small way helping to enact the school's emphasis on "Miyo-wīcēhtowin (Getting Along With Others-Expanding the Circle)" (Lessard, 2015, p. 26).

For my first meeting with Stan and Nancy, I was asked to think of possible ideas for a project, which would ideally align with my skills and interests, and which might be useful to the organization. My initial project plan was a paper zine in which the students would write their thoughts on the social justice activities and lessons they had learned through SJC. Stan, however, felt that the blog and video project was more useful to the students. While I will admit my disappointment, of course their needs were ultimately better served in that way. It was an early reminder to prioritize our community partners' objectives above our own, if indeed we were to make any meaningful contribution within the scope of the course. It was also a much-needed lesson in the kind of humility that students must assume before (or as a result of) taking on CSL work.

Whereas to some degree (and despite our readings intended to ground us in the ethics of CSL) I retained a notion that my function as the university student would be to contribute on an intellectual level in one way or another, it became clear that those running the SJC knew much more about what needed to be done than I ever would in my role as volunteer. In making the adjustment from a classroom-learning setting to a community-engaged setting, I had to unlearn behaviour on which I had previously relied, such as asking numerous clarifying questions, suggesting multiple possibilities for interpreting or acting on a particular problem, offering up unsolicited ideas at the rate of an eager seminar participant, or otherwise academicizing my duties. This process presented a clear challenge to my assumptions about the inherent value of my academic background in community-engaged contexts. In reflecting on my experience, I am reminded of the core principles of ethical scholarship with Indigenous communities-respect, reciprocity, relevance, relational accountability, and responsibility (Johnston, McGregor, \& Restoule, 2018)—all of which came to shape my experiences at Oskāyak and my understanding of what communitist service-learning must entail.

While involved with SJC at Oskāyak, I found my previous experiences with institutional structures challenged, and my efforts to be deeply educational beyond whatever preconceptions I might have had about knowledge exchange. That knowledge seemed to flow primarily out of incidental interactions with the staff and students around me, emerging from the nexus of relationships formed over the course of my service. As someone whose role was meant to be a facilitator, observer, participant, and interpreter of events, perhaps I was already receptive to whatever messages could be gleaned; however, such insights would be impossible without the relationality of a CSL model, and indeed the Cree model of inclusivity (Miyo-wīcèhtowin)

Engaged Scholar Journal: Community-Engaged Research, Teaching and Learning 
underpinning Oskāyak's pedagogy. In her discussion of CSL, Swapna Padmanabha (2018) contends that emphasizing "Indigenous pedagogies that are based on the importance of developing relationships" can help in "foster[ing] students' learning and growth by having them experience daily practices, rather than having them complete projects or service as stand-alone goals" (p. 152). This integrative practice, in which daily relationality is at the center of learning, ultimately held true in my experience at Oskāyak and my attempts to interpret the outcomes of my readings and service (which was itself rooted in the day-to-day relationships and activities of the school). Through the lens of my readings and some pre-existing knowledge of Cree philosophies, I made note of the similarities and contrasts between my own educational experience and the students' experiences at Oskāyak. Whereas I had been raised and educated in a Western secular, Euro-Canadian public school, these students were benefiting from a culturally-specific education whose mandate was to (re)integrate Indigenous philosophy and language into the daily routine. Trying to position myself carefully as an invested participant (though not a cultural insider, as a Métis raised with very little of my culture, yet acknowledging my own personal investment in the practice of revitalization and reclamation), I focused my attention on elements of our weekly readings that I might find resonating in my experiences, and conversely, I would draw upon my ever-growing experience in reading through the texts.

In two assigned readings by Tomson Highway, I found representations of Cree integrative philosophies and practices that resonated with my experience at Oskāyak. The experience, in turn, inflected and grounded my reading of the literary text, Highway's Kiss of the Fur Queen (1998), a semi-autobiographical novel about the Okimasis brothers, Champion and Ooneemeetoo (later called Jeremiah and Gabriel), as they struggle with questions of family, identity, and community in the wake of residential school. Music and dance are central to their quandaries and also to their self-discovery through daily integrative experience. In resisting colonial narratives of both "inevitable assimilation" and "inevitable victimhood" as a result of residential schooling (McKegney, 2007, p. 139), Kiss of the Fur Queen envisions modes of survivance $^{13}$ that are expressed primarily through the arts, language, and culture. The acts of creation and expression in the novel reflect a "reinvigoration of modes of thought, spirituality, and being with the world that residential schooling sought to extinguish" (McKegney, 2007, p. 144-145), and the connection of language, music, and worldview, as I will argue, is central to this process. Highway repeatedly draws the three elements together in his writing, articulating a distinctly Cree state of being in those interstices. Highway's description of a Cree sense of fluidity between language and worldview in his other writings (2008) finds an extension in Kiss of the Fur Queen's treatment of music and its relation to lived experience, which was also reflected in my experiences outside the classroom, in the community. As someone who plays and writes music outside of my academic life, I take a particular interest in how music functions in the novel, and I paid particular attention to the way that music manifested in the school. Grounded in the relational nexus of my service-learning experience, I found connections between the Cree ontology of Highway's work and that of Oskāyak High School, where

\footnotetext{
${ }^{13}$ See Vizenor (1998).
} 
language and music enact Cree integrative philosophies in their daily practice, commenting meaningfully upon each other and upon the importance of maintaining the worldview at the heart of the school.

\section{Embodied Language and Music in Highway's Theory and at Oskāyak High School}

In "Why Cree is the Sexiest of All Languages" (2008), Highway describes Cree as a profoundly humorous language, mainly because it is grounded in the human body (p. 34). The Cree relationship to the human body, reflected in the language, represents a world which is integrated with the self: nature and spirit, body and intellect are all bound up together, virtually indistinguishable. Rather than a separation or deliberate abstraction away from lived, bodily experience, the Cree language reflects a "laughing" God/Goddess in its highly embodied worldview (Highway, 2008, p. 40). A Cree sense of laughter, physical and unrelenting, is built into the landscape of Kiss of the Fur Queen; Highway uses unglossed fictitious Cree place names such as Wuchusk Oochisk, or "muskrat anus," in order to "include his fellow Cree-speaking readers in some intoxicating, silly, and giddy humour" (Van Essen, 2012, para. 9). Highway’s interpretation of the Cree language and worldview encourage enjoyment and embodiment; indeed, both elements are so closely interconnected with language that to attempt to approach Cree without them would be impossible.

Reading Highway's work in conjunction with my CSL experiences has provided some material for reflection on how language is treated at Oskāyak High School, which we may usefully position as a Cree school in Highway's extended definition of language-as-worldview. For instance, in addition to academics, Oskāyak is actively invested in cultural and spiritual aspects of student life, such as a daily smudge, semi-monthly sweats, Powwows, and a host of other ceremonies and cultural activities. The inclusion of Cree language and culture into the mandate of the school is an integrated approach, which meshes well with the concept of Cree as a language that is unified with its surroundings and situated existence. For instance, every day shortly after lunch hour, the school's Learning Leader addresses the school via the PA system with a brief "Cree Word of the Day" segment. In addition, many objects and rooms (the library, washrooms, fire extinguishers, light switches) are labeled in English and Cree-a method in which learning the language is naturalized and embedded in day-to-day life. It seemed, during my tenure with them, that many of the youth who attend Oskāyak already speak Cree with some degree of fluency. One young man, who I will refer to as David, enjoyed chatting with me on occasion, and sometimes mixed in Cree phrases, some of which I could understand and some of which I could only guess at, or piece together well after the fact. This put me in an odd position as an English-speaking Indigenous person attempting to have a conversation with someone who clearly wishes to be speaking Cree; I often found myself regretting not having more of a working knowledge of the language. Interestingly, and much to my surprise, when I attended a seminar presentation put on by the school at the Assembly of First Nations (AFN) Youth Summit in order to film the event and otherwise lend a hand, David made an enthusiastic and forthright mini-presentation about his own desire to learn his language, which he spoke as a child but which was eventually replaced by English. It overturned

Engaged Scholar Journal: Community-Engaged Research, Teaching and Learning 
my previous impressions of him as a primarily Cree speaker, and gave a new insight into his attempts to insert Cree into our conversations. He spoke about making a conscious effort to work the Cree language into his daily interactions whenever possible rather than limiting his efforts to the classroom, a very similar approach to Oskāyak's as a whole-language built into the fabric of life, rejecting compartmentalized Western approaches to knowledge.

I read a similar epistemology of music in Kiss of the Fur Queen. Much like Highway's conception of the Cree language, music in the novel's reserve village of Eemanapiteepitat is embodied and grounded in lived experience. The earliest example is the beloved jig Kimoosoom Chimasoo played on a "ratty old" accordion by Abraham Okimasis upon his triumphant return to Eemanapiteepitat after claiming victory at the Millington Cup World Championship Dog Derby (Highway, 1998, p. 308, p. 16-7). Music is situated in the day-to-day movements and events of the musician and his neighbours, serving as a binding agent for the community. Abraham's return is an occasion for celebration, it appears only natural for him to perform a victory rendition of Kimoosoom Chimasoo-which he plays "like it had never been played"and for the entire reserve to mount an impromptu "aboriginal jamboree" in response to the good news (Highway, 1998, p. 17). Even in its more solitary contexts, music on the reserve is interwoven tightly with the processes of living. A few pages following Abraham's celebratory jig, his son Champion is shown to have inherited the Okimasis musical talent, standing with Abraham's accordion on top of a rock, "singing a concert to his father and the caribou" (Highway, 1998, p. 23). Sarah Wylie Krotz (2009) notes that Champion's caribou songs, “[p] layed and sung outdoors with a spontaneity and vigour that echo his family's movements across their northern landscape, $[\ldots]$ rise out of the same energies that invigorate his everyday life" (p. 195). Three years after his first attempt at the caribou song, Champion joins with this little brother Gabriel to turn his new arrangement into a song-and-dance piece (Highway, 1998, p. 42). The combined force of their art appears to summon, out of nowhere, a massive herd of caribou (Highway, 1998, p. 41-7). The lines between art and life are constantly shifting and blurring; Highway presents a uniquely Cree merging of language, music and worldview in the early sections of Kiss of the Fur Queen.

I had a similar impression of the musical life of Oskāyak: it is integrated into the ebb and flow of the school-day, and is nearly omnipresent. Rare was the day when I would show up at the school to set up for the SJC meeting or to attend to other SJC-related business and not hear the sound of an acoustic guitar somewhere in my wanderings through the school. Most often it would be a particular young man sitting on the front steps or in a spacious upstairs hallway corner, practising with a studied yet informal sort of concentration-he would run through impeccable fingering patterns, but not to the service of any song he might be rehearsing, instead trailing in and out of different melodies as the mood suited him. His playing stood in contrast to the regimented forms of musical instruction, "stripped of the very methods by which the music has always been created, and therefore bearing little resemblance to its existence in the world outside," which tend to dominate much of music education (Green, 2003, p. 269), including its representation in Kiss of the Fur Queen. The novel's childhood scenes in northern Manitoba — and their synthesis of the material and immaterial, with language, nature, 
life, and music existing as a part of the same continuum-give way to the traumatic rupture between these elements during Jeremiah's adolescence and early adulthood. By contrast, this young man I encountered at Oskāyak displayed great skill, and though he may have appeared undisciplined in his method of practice, he was actively cultivating his abilities in the interstitial spaces of the school, becoming a part of the students' movements throughout the day.

\section{Ideologies of Music Represented in Kiss of the Fur Queen and in CSL Experience}

In a passage from Kiss of the Fur Queen representing Champion's earliest encounter with the piano as an instrument at Birch Lake residential school, the young boy finds the piano's music beautiful, though quite different in character from any music he had previously heard; the notes are "intelligent and orderly" rather than "giddy and frothy and of a nervous, clownish nature" like the accordion (Highway, 1998, p. 56). This description of the piano's sound versus the accordion's sound closely mirrors Highway's description of English versus Cree: English "may live most magnificently inside the head, in the intellect, but it stops at the neck," whereas Cree readily prompts listeners to laugh "fiercely, giddily, insanely, hysterically, from the gut" (Highway, 2008, p. 38, p. 34). The transition from accordion to piano thus signals a move toward the similarly "orderly" discipline of classical music. European theorists and critics, particularly beginning in the late eighteenth century, positioned music's primary aesthetic value as abstraction, or "separation of the musical materials involved from their human creative matrices-a manner, that is, of decontextualization" (Tomlinson, 2003, p. 37, emphasis in original). Taken to its furthest reaches, perfect music is perfect abstraction, "divorced from its contexts of production, performance, and reception” (Tomlinson, 2003, p. 39). Such lines of thinking predictably turn music into a hierarchy with Western classical music at the pinnacle. Valorized "transcendent qualities" such as "universality, complexity, originality, or autonomy" (Green, 2003, p. 264) contrast with the "communal voice" central to much traditional creative expression in Indigenous communities (Weaver, 1997, p. 41). As Gary Tomlinson (2003) notes, "It was a very short step, soon taken, [...] to the assertion of Europe as the privileged endpoint of music history" (p. 35). Fitting with this ideology, Jeremiah's later, post-residential school disdain for Indigenous musical practices "echoes some of the worst strains of colonialist rhetoric" (Krotz, 2009, p. 191) and alienates Jeremiah from his community. Jeremiah takes the position of a non-comprehending outsider, incapable of divorcing his evaluation from culturally-contingent value systems, rigidly convinced of his own cultural superiority (despite being a young Cree man himself). We may read such processes in music's wider colonial contexts. It has historically been employed, for instance, in the Jesuit missionary practice of recomposing local music as an aid to conversion; Philip Bohlman (2003) notes that these acts of "inscription and transcription" were "crucial to the acts of possession that transformed colonial encounter into forms of domination" (p. 47). By enforcing hierarchies of culture, music in these contexts can signify alienation and rigidity as much as it has the potential to inspire connection and resilience.

In the public high school I attended in my own adolescence, the hallways were silent except for the corridor where the band classrooms were located. Music had its place, designated spaces

Engaged Scholar Journal: Community-Engaged Research, Teaching and Learning 
in which the art could be practised, and public singing or guitar-playing, particularly during class time, would most likely have been treated as a nuisance. Social judgment may also have been a discouragement to a more widespread practice of music. Practice, in a Euro-Canadian culture where the "heightened public experience" of a concert is the norm (Said, 1991, p. 10), is something to be done in private or in secret. Only the performance is acceptable-anything else is viewed as imperfection or incompletion. In contrast, at Oskāyak it seems that music is not contained. Along with guitar music, quiet singing from some of the young women in the school can be heard on most days. The kitchen helpers who lend a hand to the school's main cook would often break into small snippets of songs here and there. On one or two occasions, the helpers had nothing to do for a few minutes and gathered around a laptop computer which was playing music in the cafeteria, trying to sing a song all together. Their singing caught me off guard the first time it happened, being in a public place and in the presence of a stranger (myself). On another occasion, the school's Media Lab was deserted but for a young woman I had not met. We exchanged brief pleasantries as she settled into her workstation, and before long she started playing her choice of music (as opposed to the radio station which was also playing in the background), half-singing along to the same song several times in a row as she did other things on the computer. The marvel for me was that this young woman seemed to feel comfortable enough, in the presence of someone she had never met, to idly practice singing along to song-not uncommon behaviour of itself, but in my experience much less common in the presence of others.

Such experiences throw the practices of music in Kiss of the Fur Queen into sharp relief. The music into which Jeremiah immerses himself in Winnipeg is highly formalized classical training, relying upon solitude, strict coaching and ritualized practice. In much the same way that the split between language and nature, body and intellect, reflects a split worldview, music in the specialized classical European tradition distances itself from the more natural processes of musicality as shown in Champion's caribou songs. The process of grappling with Bach's D-major Toccata and its "rollicking, reel-like beat" evokes the dances from home - music placed in its rightful communal context - as visions of his neighbours and relations "tugged at his heart - 'Come home, Jeremiah, come home [...]"' (Highway, 1998, p. 101). This passage, though illustrative of alienating educational practices, also emphasizes the persistence of the worldly in the face of enforced abstraction, and the inevitable tug of home. Ultimately, Jeremiah and Gabriel do decide to collaborate through the medium of theatre after years of estrangement, and their reconnection signals the creation of an integrated form of music, to take both of them back to the sense of magic they experienced as children growing up in a fundamentally musical world. The very landscape in which the Okimasis brothers go through childhood provides "a rich universe of sound" in which music "seems to rise, independent of human agency, out of the natural rhythms of the world itself" (Krotz, 2009, p. 185). The fluidity with which the brothers approach their creative process is the antithesis of the forced separation, abstraction, and "regimentation" (McKegney, 2007, p. 165) of the educational and artistic structures which caused their personal and spiritual alienation to occur. 


\section{Integrative Practices of Relationality at Oskāyak}

Looking toward my experiences at Oskāyak, and recognizing that the school is still firmly entrenched within the Canadian educational system, I also posit that the integrative nature of their knowledge practices, relationality models, and creative supports (manifested in the students' experiences as well as my own) gestures toward the same kind of praxis that Highway affirms in Kiss of the Fur Queen. The unique environment at Oskāyak contributes to this praxis; it is a small school, with approximately two hundred to three hundred students in total, most of whom share a similar cultural background. The student/teacher structures at Oskāyak also differ significantly from the standard Western model; teachers are referred to by first name, and their relationship with the students is of a markedly different dynamic than at most public high schools. One student at the Youth Summit described his relationship with the teachers as more of a friendship than a matter of authority, and at times the students teased the teachers mercilessly. The hierarchical academic relationship has here been collapsed down to a more egalitarian model, making strides toward dismantling the power dynamics which have been so harmful to Indigenous students in past and present generations. This type of relationality is in line with Oskāyak's mandate of decolonizing teacher-student relationships and pursuing a learning atmosphere in which Indigenous values of kinship and mutual respect are at the center of the educational process (Lessard, 2015, p. 16-18). In an institution which supports students' creative pursuits in the hallways and corners, computer labs and kitchens, which goes so far as to host informal jam sessions as a popular means of building community and encouraging creative growth, I read deliberate refusal of Western hierarchies and regulation. There are many community-binding agents at play here, and Oskāyak's approach to language and music, supported by an informal overall authority structure, mirrors Highway's use of Cree as a worldview, suggests that such an approach is beneficial to the specific needs of its students, and decenters the classroom model to which I had become accustomed over the course of my own education, thus forcing me to reconsider my position as a graduate student offering service to a community I had come to view as outside my purview at the university.

As resonances between the texts and my experience built upon one another over the course of the term, I found some clarity of focus for considering the Cree philosophies and relationality practices that underpin them both, though the deeper implications of those resonances are still making themselves known to me. Foremost among future CSL considerations is the kind of radical repositioning made possible by Oskāyak's Miyo-wīcēhtowin kinship model and Highway's emphasis on the integrative connections between daily community life, art, and language. I've come to view my ability to interpret the experience and text as so closely intertwined to be the result of the overarching structure of my engagement itself. Had my community partner not upheld their inclusive and non-hierarchichal institutional structure and philosophy, and had my involvement not focused upon the daily movements and relationships of the student body, those connections may have remained opaque to me.

\section{Conclusion: Communitist Scholarship as Integrative Practice}

"Why Cree is the Sexiest of All Languages," Tomson Highway's comparative essay on the 
Cree and English languages and their respective implications for worldview, indicates a Cree that is, in contrast to English, very much a part of the world around it: integrated with nature, body, and community. In Kiss of the Fur Queen, similar use is made of music as an extension of worldview, with Cree music situated in its natural surroundings and community. Along similar lines, JD has considered their experiences working with the students at Oskāyak High School in light of Highway's essay, and has found that in many ways it is very much a Cree high school, integrating language and music in a way that resists Eurocentric compartmentalization. JD's analysis prompts reflection on the possibilities inherent in bridging lived experience, relationships, and learning; at Oskāyak, these elements all flow into one another and into the lives of the students, and they must be treated as part of the same continuum. This integrative praxis spurs our collective reflection upon the limitations of previous academic experience and highlights the necessity of adopting similar principles for scholarship and activism. We find numerous resonances between readings of experience and text, and these resonances suggest future approaches to responsible engaged scholarship and community involvement. Through the case study of communitist literary scholarship we have presented in this essay, we aim to provoke a critical re-examination of scholarly convention, highlighting the inseparability of artistic and intellectual work from lived experience, as well as the necessity and centrality of community to knowledge production, in particular the relationality and responsibility central to CSL practice.

\section{About the Authors}

JD McDougall is a Métis doctoral candidate in the English Department at the University of Saskatchewan, whose dissertation focuses on Métis family narratives.

Nancy Van Styvendale (corresponding author) is an Associate Professor in the Faculty of Native Studies at the University of Alberta who researches and teaches in the fields of Indigenous North American literatures, Indigenous prison writing, and community-engaged learning. Nancy has developed a number of collaborative, community-based teaching and research projects, including Inspired Minds, a creative writing program for people incarcerated in Alberta and Saskatchewan. Email: vanstyve@ualberta.ca 


\section{References}

Absolon, K., \& Willett, C. (2005). Putting ourselves forward: Location in Aboriginal research. In L. Brown and S. Strega (Eds.), Research as resistance: Critical, Indigenous, and anti-oppressive approaches (pp. 97-126). Toronto, ON: Canadian Scholars' Press.

Bain, M. (2018). Community-university engagement: Case study of a partnership on Coast Salish territory in British Columbia. Engaged Scholar Journal, 4(1), 123-141.

Bohlman, P. V. (2003). Music and culture: Historiographies of disjuncture. In M. Clayton, T. Herbert, \& R. Middleton (Eds.), The cultural study of music: A critical introduction (pp. 45-56). New York, NY: Routledge.

Buhler, S., Settee, P., \& Van Styvendale, N. (2014). Teaching and learning about justice through wahkohtowin. Annual Review of Interdisciplinary Justice Research, 4, 182-210.

Buhler, S., Settee, P., \& Van Styvendale, N. (2015). "We went in as strangers, and left as friends": Building community in the wahkohtowin classroom. Engaged Scholar Journal, 1(2), 96-115.

Butin, D.W. (2003). Of what use is it? Multiple conceptualizations of service learning within education. Teachers College Record, 105(9), 1674-1692.

Butin, D.W. (2010). Service-learning in theory and practice: The future of community engagement in higher education. New York, NY: Palgrave Macmillan.

Eagleton, T. (2008). Literary theory: An introduction. Minneapolis, MN: University of Minnesota.

Gaudet, C. J. (2019). Keeoukaywin: The visiting way-fostering an Indigenous research methodology. Aboriginal Policy Studies, 7(2), 47-64.

Gaudry, A. (2018). Next steps in Indigenous community-engaged research: Supporting research self-sufficiency in Indigenous communities. In K. T. Carlson, J. S. Lutz, D.M. Schaepe, \& Naxaxalhts'i (Eds.), Towards a new ethnohistory: Community-engaged scholarship among the people of the river (pp. 255-259). Winnipeg, MB: University of Manitoba.

Gaudry, A. (2011). Insurgent research. Wicazo Sa Review, 26(1), 113-136.

Green, L. (2003). Music education, cultural capital, and social group identity. In M. Clayton, T.

Herbert, \& R. Middleton (Eds.), The cultural study of music: A critical introduction (pp. 263-273). New York, NY: Routledge.

Grobman, L., \& Rosenberg, R. (2015). Literary studies, service learning, and the public humanities. In L. Grobman, \& R. Rosenberg (Eds.), Service learning and literary studies in English (pp. 1-39). New York, NY: Modern Language Association.

Goulet, L. M., \& Goulet, K. N. (2014). Teaching each other: Nebinuw concepts \& Indigenous pedagogies. Vancouver, BC: University of British Columbia.

Haig-Brown, C., Hodgson-Smith, C. L., Regnier, R., \& Archibald, J. (Eds.). (1997). Making the spirit dance within: Joe Duquette High School and an Aboriginal community. Boston, MA: Formac.

Henry, R., Tait, C., \& STR8 UP. (2016). Creating ethical research partnerships-Relational accountability in action. Engaged Scholar Journal, 2(1), 183-204.

Highway, T. (1998). Kiss of the Fur Queen. Toronto, ON: Anchor Canada.

Highway, T. (2008). Why Cree is the sexiest of all languages. In D. H. Taylor (Ed.), Me sexy (pp.

33-40). Vancouver, BC: Douglas and McIntyre.

Himley, M. (2004). Facing (up to) "the stranger" in community service-learning. College Composition and Communication, 55(3), 416-438.

Engaged Scholar Journal: Community-Engaged Research, Teaching and Learning 
Hitchings, P., Johnson, C., and Tu'Inukuafe, S. (2018). Challenges and opportunities of community service-learning: Phaedra Hitchings, Chantelle Johnson, and Stan Tu'Inukuafe in conversation with Sarah Buhler and Nancy Van Styvendale. Engaged Scholar Journal, 4(1), 271-281.

Hodgson, H. (1999). Survival Cree, or Weesakeechak dances down Yonge Street: Heather Hodgson speaks with Tomson Highway. Books in Canada, 28(1), 2-5.

Innes, R.A. (2009). "Wait a second. Who are you anyways?" The insider/outsider debate and American Indian Studies. American Indian Quarterly, 33(4), 440-461.

Johnston, R., McGregor, D., \& Restoule, J.P. (2018). Relationships, respect, relevance, reciprocity, and responsibility: Taking up Indigenous research approaches. In D. McGregor, J. P. Restoule, \& R. Johnston (Eds.), Indigenous research: Theories, practices, relationships (pp. 1-21). Toronto, ON: Canadian Scholars' Press.

Justice, D. H. (2018). Why Indigenous literatures matter. Waterloo, ON: WLU Press.

Krotz, S. W. (2009). Productive dissonance: Classical music in Tomson Highway's Kiss of the Fur Queen. Studies in Canadian Literature, 34(1), 182-203.

Lessard, S. (2015). Greater Saskatoon Catholic schools Indigenous education initiative: Oskaayak "young people" high school. Retrieved from https://indspire.ca/nurturing-capacities/greater-saskatooncatholic-schools-indigenous-education-initiative-oskayak-young-people-high-school-2/

McKegney, S. (2007). From Trickster poetics to transgressive: Substantiating survivance in Tomson Highway's Kiss of the Fur Queen. In Magic weapons: Aboriginal writers remaking community after residential school (pp. 137-173). Winnipeg, MB: University of Manitoba.

McKegney, S., \& Henzi, S. (2016). Indigenous literatures and the arts of community: Editors' afterword. Canadian Literature 230-231. Retrieved from https://canlit.ca/article/indigenousliteratures-and-the-arts-of-community-editors-afterword/

McNally, M. D. (2004). Indigenous pedagogy in the classroom: A service learning model for discussion. American Indian Quarterly, 28(3-4), 604-617.

Mitchell, T. (2008). Traditional vs. critical service-learning: Engaging the literature to differentiate two models. Michigan Journal of Community Service Learning, 14(2), 50-65.

Padmanabha, S. (2018). Indigenous methods and pedagogy: Revisiting ethics in community servicelearning. Engaged Scholar Journal, 4(1), 143-160.

Pompa, L. (2013). Drawing forth, finding voice, making change: Inside-out leaning as transformative pedagogy. In S. W. Davis and B. S. Roswell (Eds.), Turning teaching inside out: A pedagogy of transformation for community-based education (pp. 13-26). New York, NY: Palgrave Macmillan.

Reder, D. (2016). Introduction: Position. In D. Reder and L. Morra (Eds.), Learn, teach, challenge: Approaching Indigenous literatures (pp. 7-17). Waterloo, ON: WLU Press.

Said, E. W. (1991). Musical elaborations. New York, NY: Columbia University.

Smith, L. T. (1999). Decolonizing methodologies: Research and Indigenous peoples. London, UK: Zed Books.

TallBear, K. (2017). Standing with and speaking as faith: A feminist-Indigenous approach to inquiry. In C. Andersen \& J. O’Brien (Eds.), Sources and methods in Indigenous Studies (pp. 78-85). New York, NY: Routledge.

Taylor, A., Butterwick, S., Raykov, M. Glick, S., Peikazadi, N., \& Mehrabi, S. (2015). Community servicelearning in Canadian higher education. Vancouver, BC: University of British Columbia. Retrieved from https://open.library.ubc.ca/cIRcle/collections/facultyresearchandpublications/52383/ items/1.0226035 
Tomlinson, G. (2003). Musicology, Anthropology, History. In M. Clayton, T. Herbert, \& R.

Middleton (Eds.), The cultural study of music: A critical introduction (pp. 31-44). New York, NY: Routledge.

Van Essen, A. (2012). Nêhiyawaskiy (Cree land) and Canada: Location, language, and borders in Tomson Highway's Kiss of the Fur Queen. Canadian Literature, 215, 104-118. Retrieved from http://cyber.usask.ca/login?url=http://search.ebscohost.com/login.aspx?direct=true $\& \mathrm{db}=\mathrm{a} 9 \mathrm{~h} \& \mathrm{AN}=88132245 \&$ site $=$ ehost-live

Van Styvendale, N., Buhler, S., \& McDonald, J. (2018). CSL in Canada: Emerging conversations. Engaged Scholar Journal, 4(1), i-xiii.

Vizenor, G. (1998). Fugitive poses: Native American Indian scenes of absence and presence. Lincoln, NE: University of Nebraska.

Weaver, J. (1997). That the people might live: Native American literatures and Native American community. New York, NY: Oxford University.

Westheimer, J., \& Kahne, J. (2004). Educating the 'good' citizen: Political choices and pedagogical goals. PSOnline, 241-247. 